\title{
Isolated atrial amyloid contains atrial natriuretic peptide: a report of six cases
}

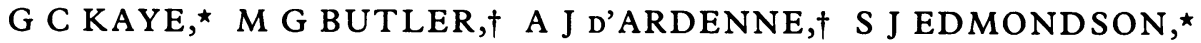

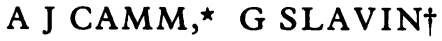 \\ From the Departments of ${ }^{\star}$ Cardiology and $\dagger$ Histopathology, St Bartholomew's Hospital, London
}

SUMMARY Twenty five specimens of the human right atrial appendage were examined for immunoreactivity to $\alpha$ human atrial natriuretic peptide. In the electron microscope characteristic amyloid fibrils were identified around small blood vessels and adjacent to atrial muscle cells in eight of the surgical cases and in two necropsy cases. In six cases, four surgical and two necropsy, these fibrils contained immunoreactive $\alpha$ human atrial natriuretic peptide. Amyloid is known to occur in peptide secreting endocrine tumours and immunoreactive peptide may be incorporated in the amyloid matrix. The demonstration of atrial amyloid containing immunoreactive $\alpha$ human atrial natriuretic peptide suggests that some deposits of cardiac amyloid are of a type analogous to that found in other endocrine organs.

Amyloidosis is a disorder characterised by the deposition of an abnormal protein usually in the extracellular tissues. It occurs as a primary disease process or secondary to several diverse conditions and the nature of the protein may differ from type to type. Amyloid has characteristic chemical staining reactions and is best defined by its appearance on electron microscopy which shows fine nonbranching fibrils approximately $10 \mathrm{~nm}$ in diameter. Amyloid deposits occur in endocrine organs and may contain hormone related peptides. ${ }^{1}$ For example, immunoreactive calcitonin is found in amyloid deposits associated with medullary carcinoma of the thyroid. ${ }^{23}$

It is now thought that the heart has an important endocrine role in the control of body fluid volume. Small molecular weight peptides have been isolated from the human atria and these have powerful natriuretic and diuretic effects. ${ }^{4}$ Of these, the $\alpha$ human atrial natriuretic factor is believed to be the active circulating form. These peptides have been localised to neurosecretory granules within atrial muscle cells.

During a study of the distribution and staining characteristics of neurosecretory granules in the

Requests for reprints to Dr G C Kaye, Department of Cardiology, St Bartholomew's Hospital, West Smithfield, London EC1A 7BE.

Accepted for publication 8 July 1986 human right atrial appendage several cases of amyloid were coincidentally seen. In this report we describe the immunohistochemical localisation of $\alpha$ human natriuretic peptide to amyloid fibrils in the human atrial appendage. This finding suggests that some deposits of cardiac amyloid are of a type analogous to those found in other endocrine organs.

\section{Patients and methods}

Twenty two right atrial appendages were obtained at the time of cardiac bypass surgery from patients aged 19-73 years. Three right atrial appendages were obtained at necropsy from patients aged 53 (male), 71 (male), and 88 (female) years. Tissue was removed 24, 48, and 72 hours after death respectively. Two samples of ventricular tissue were also studied, one obtained at necropsy and the other at surgery for ventricular tachycardia.

All of the surgical patients had ischaemic heart disease with or without previous infarction and none was known to have disease processes usually associated with amyloidosis. None had congestive cardiac failure. One patient had an aortic valve replacement in addition to coronary bypass surgery and one patient (a man of 43) had preoperative paroxysmal atrial fibrillation. There were no other reported rhythm disturbances. The patient with ventricular tachycardia had right ventricular dysplasia. Table 1 shows the clinical details and cause of death in the necropsy cases. 
Table 1 Clinical details and cause of death in patients in whom tissue was obtained at necropsy

\begin{tabular}{|c|c|c|}
\hline Age (yr) & Clinical details & Cause of death \\
\hline $\begin{array}{l}53 \\
71\end{array}$ & $\begin{array}{l}\text { Hypertension } \\
\text { Peripheral vascular } \\
\text { disease, hypertension }\end{array}$ & $\begin{array}{l}\text { Cerebrovascular accident } \\
\text { Myocardial infarction }\end{array}$ \\
\hline 88 & $\begin{array}{l}\text { Senile dementia, previous } \\
\text { cerebrovascular accident }\end{array}$ & Pulmonary embolism \\
\hline
\end{tabular}

\section{METHODS}

The method of immunohistochemical staining has been reported elsewhere. ${ }^{5}$ In brief, a piece of right atrial appendage was pinned out and fixed in paraformaldehyde lysine sodium periodate for 24 hours. Tissue for routine paraffin histological examination was stained for amyloid by Congo red, sulphated alcian blue, and tryptophan. For immunoelectron microscopy tissue was embedded into an acrylic resin. Ultra thin sections were cut at $50-70 \mathrm{~nm}$, placed on uncoated nickel grids, and stained for atrial natriuretic peptide by indirect immunohistochemical labelling with a $15 \mathrm{~nm}$ colloidal gold probe. The rest of the tissue was fixed in glutaraldehyde and osmium tetroxide for standard elecron microscopical examination.

The antiserum was also applied to necropsy tissue from the ventricle of a middle aged man with primary cardiac amyloid and to ventricular tissue obtained at surgery that showed no visible amyloid. Control immunocytochemical tests were performed with primary antiserum preabsorbed with synthetic atrial natriuretic peptide or with non-immune rabbit serum.

\section{Results}

The age range of the eight patients with amyloid was 43-73 years (mean 60). In eight surgical and two necropsy cases (table 2) ultrastructural examination of the atrial tissue showed fine deposits of amyloid fibrils 7-10 nm in diameter around small blood vessels (arterioles) and adjacent to muscle cells (table 2). None was seen around larger blood vessels. Intracellular amyloid was seen in two cases (fig 1 ). In four surgical and two necropsy cases the fibrils were clearly and consistently labelled for immunoreactive atrial natriuretic peptide (fig 2). Background labelling of the surrounding connective tissue was negligible. In addition, in all patients immunoreactive atrial natriuretic peptide was demonstrated in the neurosecretory granules within atrial muscle cells (fig 3), which were frequently adjacent to the cell membrane. There was close association between immunoreactive extracellular amyloid deposits and
Table 2 Cases of ischaemic heart disease that were positive for amyloid and atrial natriuretic peptide ( $A N P$ )

\begin{tabular}{cc}
\hline Surgical & Necropsy \\
22 cases & $\downarrow$ \\
8 positive for amyloid \\
$\downarrow$ \\
4
\end{tabular}

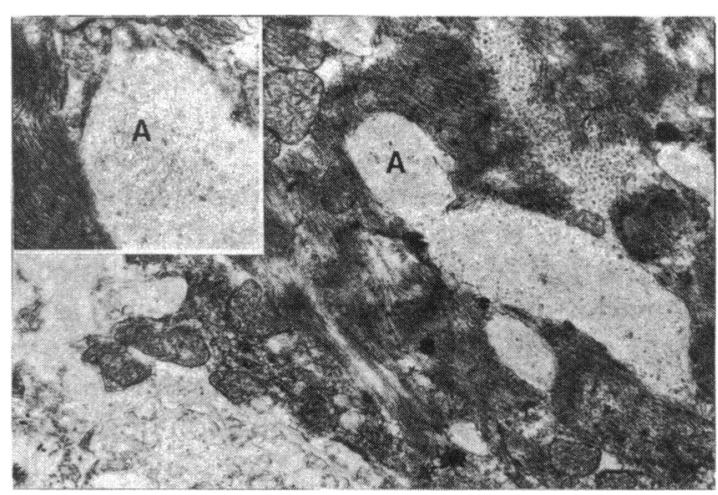

Fig 1 Electronmicrograph showing intracellular amyloid deposits $(A)$ in an atrial muscle cell in atrial appendage tissue fixed in glutaraldehyde and osmium tetroxide.

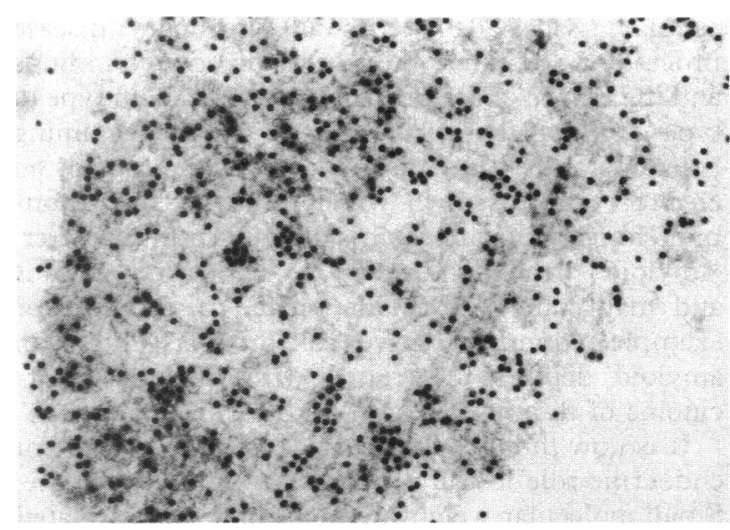

Fig 2 Electronmicrograph showing extracellular amyloid in necropsy tissue from the atrial appendage. Amyloid fibrils are clearly labelled with immunogold (15 nm gold balls) for atrial natriuretic peptide.

neurosecretory granules in amyloid positive patients (fig 4).

In tissue obtained at surgery amyloid was not detected by light microscopy and the Congo red stain was negative. Reaction with preabsorbed antiatrial natriuretic peptide was consistently negative. In one tissue sample obtained at necropsy from an 88 year old patient, fine deposits of amyloid were 


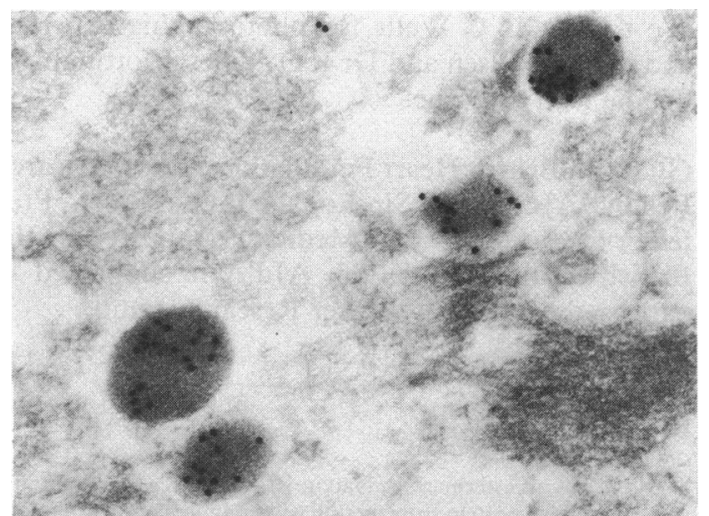

Fig 3 Electronmicrograph showing atrial natriuretic peptide demonstrated by immunogold labelling (15 nm gold balls) in neurosecretory granules in an atrial muscle cell.

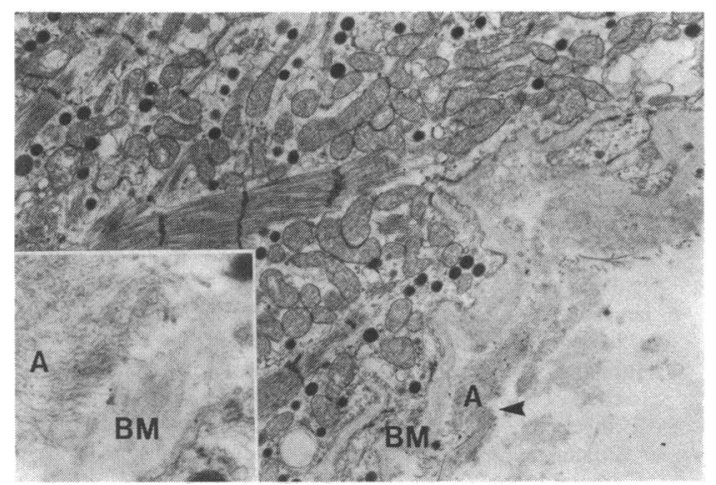

Fig 4 Electronmicrograph showing neurosecretory granules at the periphery of an atrial muscle cell. Amyloid $(A)$ is external to the basement membrane (BM). (Tissue fixed in glutaraldehyde and osmium tetroxide.)

seen by light microscopy. They stained negatively for tryptophan and equivocally for atrial natriuretic peptide.

Neurosecretory granules were not demonstrated in the ventricular tissue examined. A sample from the case of ventricular amyloid, obtained at necropsy, was positive for amyloid by light microscopy. This stained positively for tryptophan but did not react with the antiserum to atrial natriuretic peptide.

The three cases in which tissue was obtained 24, 48 , and 72 hours after death were assessed for preservation of immunoreactive atrial natriuretic peptide. All had neurosecretory granules that stained positively for atrial natriuretic peptide. Tissue from the 71 and 88 year old patients, obtained 48 and 72 hours after death respectively, showed isolated atrial amyloid. This stained positively for atrial natriuretic peptide.

\section{Discussion}

The aetiology of cardiac amyloid is unknown. Clinical cardiac amyloidosis is a rare disorder in which other organs may or may not be affected. Amyloid deposits sufficient to produce cardiac dysfunction are seldom limited to the heart and are often part of a systemic disorder. Cardiac amyloidosis produces a restrictive type of cardiomyopathy and may present as congestive cardiac failure or with arrhythmias and conduction disturbances that are often associated with sudden death. ${ }^{67}$

More commonly, amyloidosis occurs in a localised form as a manifestation of aging. Two types have been described; that affecting both the ventricles and atria, known as senile cardiac amyloid, and that affecting the atria alone, known as isolated atrial amyloid. ${ }^{8}$ Elderly patients often have small deposits of amyloid in the heart, which rarely cause clinical symptoms although a higher incidence of atrial fibrillation has been noted. ${ }^{8}$ Isolated atrial amyloid has been reported in $78 \%$ of patients over the age of 80 years. $^{8}$ Although they are of similar ultrastructural appearance these two forms of cardiac amyloid differ chemically. Senile cardiac amyloid contains easily demonstrable tryptophan, whereas isolated atrial amyloid does not. ${ }^{9}$ In the electron microscope Westermark et al observed differences in the type and distribution of cardiac amyloid. ${ }^{10}$ They noted that isolated atrial amyloid occurred as fine deposits in or adjacent to the sarcolemma of muscle cells and affected small vessels. Senile cardiac amyloid occurred as larger deposits, often compressing muscle bundles and heavily infiltrating small and medium sized arteries. Only isolated atrial amyloid was found as intracellular deposits. ${ }^{10}$ In the present series the distribution and morphological characteristics of the amyloid closely resemble these observations. Intracellular amyloid is also known to occur in endocrine tumours. ${ }^{11}{ }^{12}$

Endocrine associated and isolated atrial amyloid are histochemically similar in that, unlike other forms of amyloid, they do not contain tryptophan. ${ }^{913}$ We have confirmed the findings for tryptophan staining in patients with senile cardiac amyloid, systemic amyloidosis, and in several tumours containing endocrine amyloid, as well as in isolated atrial amyloid, the latter two conditions being consistently negative for tryptophan.

The discovery of peptides stored within granules in the atria supports the concept that the heart has an endocrine function in the control of body fluids. ${ }^{14}$ These peptides have powerful natriuretic, diuretic, and vasodilatory actions ${ }^{4}$ and are believed to be stored as a proprecursor molecule within neurosecretory granules. In man the proprecursor is 
ultimately cleaved into three distinct peptides, $\alpha, \beta$, and $\gamma .{ }^{15}$ The $\alpha$ human atrial natriuretic peptide is believed to be the active circulating form and has been measured in the peripheral circulation. ${ }^{16} \mathrm{It}$ is 28 amino acid residues in length and does not contain tryptophan.

We found immunoreactive $\alpha$ human atrial peptide within atrial amyloid fibrils and demonstrated its presence in the close anatomical association with neurosecretory granules within atrial muscle cells. It is morphologically similar to previous descriptions of isolated atrial amyloid. This supports the concept that some isolated atrial amyloid is of the endocrine associated type and that atrial natriuretic peptide or its precursor may be its primary constituent. In four surgical atrial specimens, however, amyloid did not contain $\alpha$ human atrial natriuretic peptide. There may be several explanations for this. The deposits may represent an early manifestation of generalised cardiac involvement either senile in type or of a clinical secondary type. Alternatively, the negative fibrils may be of an endocrine associated type whose peptides were not recognised by the antiserum. Because ventricular tissue or tissue from other organs was not available in these four cases we are unable to follow this point further.

Previously reported series in which light microscopy was used indicate that both isolated atrial amyloid and senile cardiac amyloid occur with increasing age, ${ }^{1718}$ usually above the age of 80 years. $^{8}$ In our series the surgical patients were considerably younger. We saw small deposits of amyloid by light microscopy in tissue obtained at necropsy from an 88 year old woman. This patient was in the typical age range for isolated atrial amyloid. It is interesting to speculate that deposits of amyloid may accumulate asymptomatically earlier in life than had been appreciated and that this is only revealed by electron microscopy. In the elderly population it has been suggested that atrial fibrillation is more common in patients with isolated atrial amyloid. ${ }^{8}$ It would be difficult to demonstrate levels of cardiac amyloid in younger patients with paroxysmal or sustained atrial fibrillation but the possibility of an association is intriguing.

Cantin et al observed immunoreactive atrial natriuretic peptide in neurosecretory granules in atrial tissue obtained within 10 hours of death. ${ }^{19}$ However, we have demonstrated immunoreactive atrial natriuretic peptide within neurosecretory granules and amyloid in tissue obtained up to 72 hours after death. This had similar staining characteristics to surgical tissue and this allowed adequate characterisation of atrial natriuretic peptide staining in necropsy tissue. A study is currently under way into the incidence and distribution of atrial amyloid in all age groups and its relation to atrial natriuretic peptides.
We thank Mr C Wells for photographic expertise and to Dr E Olsen and Dr P D James (Nottingham) for the loan of tissue.

GCK is a British Heart Foundation Junior Research Fellow. AJC is the Sir Ronald Bodley Scott Professor of Cardiovascular Medicine supported by the British Heart Foundation. AJd'A is supported in part by the Imperial Cancer Research Fund.

\section{References}

1 Sletten K, Westermark P, Natvig JB. Characterisation of amyloid fibril protein from medullary carcinoma of the thyroid. $\mathcal{J}$ Exp Med 1976;143:993-8.

2 Butler MG, Khan S. Immunoreactive calcitonin in amyloid fibrils of medullary carcinoma of the thyroid: an immunogold technique. Arch Pathol Lab Mea 1986;110:647-9.

3 Dammwich J, Ormans W, Schaffer K. Electron microscopic demonstration of calcitonin in human medullary carcinoma of the thyroid by the immunogold staining method. Histochemistry 1984;81:369-72.

4 Cantin M, Genest J. The heart and atrial natriuretic factor. Endocr Rev 1985;6:107-27.

5 Kaye GC, Butler MG, D'Ardenne AJ, Edmondson S, Camm AJ, Slavin G. Identification of immuno-reactive atrial natriuretic peptide within atrial amyloid. $\mathcal{F}$ Clin Pathol 1986; 39:581-2.

6 James TN. Pathology of the cardiac conduction system in amyloidosis. Ann Intern Med 1966;65:28-36.

7 Hurst JW. Amyloid disease of the heart. In: Hurst JW, ed-inchief. The heart. New York: McGraw-Hill, 1982:1327.

8 Cornwell GG III, Murdoch WL, Kyle RA, Westermark P, Pitkanen $P$. Frequency and distribution of cardiovascular amyloid. $A m$ f Med 1983;75:618-23.

9 Westermark P, Johansson B, Natvig JB. Senile cardiac amyloidosis; evidence of two different amyloid substances in the ageing heart. Scand $\mathcal{F}$ Immunol 1979;10:303-8.

10 Westermark P, Cornwell GG III, Johansson B, Natvig JB. Senile cardiac amyloidosis. In: Glenner GG, Costa PP, Falcao de Freites A, eds. Amyloid and amyloidosis. Amsterdam: Excerpta Medica Foundation, 1980:217-25.

11 Westermark P, Grimelius L, Polak JM, et al. Amyloid in polypeptide hormone producing tumours. Lab Invest 1977;37:212-5.

12 Williams ED, Brown CL, Doniach I. Pathological and clinical findings in a series of 67 cases of medullary carcinoma of the thyroid. 7 Clin Pathol 1966;19:103-13.

13 Pearse AGE, Ewen SWB, Polak JM. The genesis of Apudamyloid in endocrine polypeptide tumours: histochemical distinction from immunamyloid. Virchows Archiv Abteilung B. Zellpathologie 1972;10:93-107.

14 Kaye GC, Camm AJ. The role of the atria in fluid volume control. Br f Hosp Med 1985;34:82-8.

15 Kangawa $K$, Fukuda A, Matsuo $H$. Structural identification of beta and gamma human atrial natriuretic polypeptides. Nature 1985;313:397-400.

16 Yanaji $T$, Ishibashi $M$, Takaku F. Atrial natriuretic factor in human blood. $f$ Clin Invest 1985;76:1705-9.

17 Pomerance A, Slavin G, McWatt J. Experience with the sodium sulphate-Alcian blue stain for amyloid in cardiac pathology. f Clin Pathol 1976;29:22-6.

18 Pomerance A. Senile cardiac amyloidosis. $\mathrm{Br}$ Heart $\mathrm{f}$ 1965;27:711-8.

19 Cantin M, Gutkowska J, Thibault G, et al. Immunocytochemical localisation of atrial natriuretic factor in the heart and salivary gland. Histochemistry 1984;80:113-27. 